\title{
Correction: A narrative review on cervical interventions in adults with chronic whiplash-associated disorder
}

Anderson C, Yeung E, Toong T, et al. A narrative review on cervical interventions in adults with chronic whiplash-associated disorder. BMJ Open Sport Exerc Med 2018;4:e000299. doi: 10.1136/bmjsem-2017-000299

The authors want to alert readers to the following error identified in the published version.

One of the co-authors' name was misspelled. The correct name should have been Tiffany Toong instead of Tiffany Tong.

Open access This is an Open Access article distributed in accordance with the Creative Commons Attribution Non Commercial (CC BY-NC 4.0) license, which permits others to distribute, remix, adapt, build upon this work non-commercially, and license their derivative works on different terms, provided the original work is properly cited and the use is non-commercial. See: http://creativecommons.org/licenses/by-nc/4.0/

C Author(s) (or their employer(s)) 2018. Re-use permitted under CC BY-NC. No commercial re-use. See rights and permissions. Published by BMJ.

BMJ Open Sport Exerc Med 2018;4:e000299corr1. doi:10.1136/bmjsem-2017-000299corr1

A) Check for updates 